\title{
Perception of the peruvian student, is the virtual reality alternative of sustainability of the tourist destinations?
}

\section{Percepción del estudiante peruano ¿la realidad virtual es alternativa de sostenibilidad de los destinos turísticos?}

\begin{abstract}
María del Pilar Quezada Castro ${ }^{*}$, María del Pilar Castro Arellano ${ }^{2}$, Juan Manuel Oliva Núñez ${ }^{3}$, Carlos Ignacio Gallo Aguila ${ }^{4}$ \& Guillermo Alexander Quezada Castro 5

\footnotetext{
${ }^{1}$ Abogada, Maestro en Derecho Civil, egresada de la Escuela Profesional de Turismo, Hotelería y Gastronomía, Doctorando en Educación. Universidad Tecnológica del Perú, sede Piura, correo: c20853qutp.edu.pe

${ }^{2}$ Abogada, Maestro en Derecho Civil, Doctor en Derecho, egresada de la Escuela Profesional de Turismo, Hotelería y Gastronomía. Coordinadora Académica de la Escuela Profesional de Turismo, Hotelería y Gastronomía de la Universidad Alas Peruanas, filial Piura, correo: m_castro_aquap.edu.pe

${ }^{3}$ Arqueólogo, Maestro en Educación con mención en Investigación y Docencia, Doctor en Ciencias de la Educación. Coordinador de la oficina de Investigación, Innovación y Emprendimiento de la Universidad Alas Peruanas, Piura, correo: __oliva(adoc.uap.edu.pe

${ }^{4}$ Ingeniero Industrial, Maestro en Docencia Universitaria y Gestión Educativa, Doctor en Ciencias de la Educación, Docente de la Universidad César Vallejo, Piura, correo: cgalloa(agmail.com

${ }^{5}$ Abogado, Maestro en Derecho Civil, egresado del Doctorado en Derecho. Universidad Alas Peruanas, filial Piura, correo: g_quezada_cądoc.uap.edu.pe
}

*Corresponding author: c20853qutp.edu.pe

\section{ABSTRACT}

The business sector linked to tourism could be affected as a consequence of the pandemic - Coronavirus, for this, it was considered necessary to know the perception of the university student, who was asked about the incorporation of virtual reality in the development of traditional tourism. The methodology includes the positivist paradigm, quantitative approach, analytical method, non-experimental design, descriptive level and transectional type. A questionnaire was applied to 147 university students from the Piura Region - Peru, belonging to the Faculties of Administration and Tourism. The results obtained allow us to conceive that the perception of the Peruvian university student is positive in relation to the implementation of virtual reality as a complementary service in the tourism sector, the need to know Information and Communication Technologies - ICT, the sustainability of tourist destinations and respect for the environment.

Keywords: Virtual reality, sustainability, tourist destination

\section{RESUMEN}

El sector empresarial vinculado con el turismo podría ser afectado como consecuencia de la pandemia - Coronavirus, para ello, se consideró necesario conocer la percepción del estudiante universitario, a quien se le preguntó respecto a la incorporación de la realidad virtual en el desarrollo del turismo tradicional. La metodología comprende el paradigma positivista, enfoque cuantitativo, método analítico, diseño no experimental, nivel descriptivo y tipo transeccional. Se aplicó un cuestionario a 147 estudiantes universitarios de la Región Piura - Perú, pertenecientes a las Facultades de Administración y Turismo. Los resultados obtenidos permiten concebir que la percepción del estudiante universitario peruano es positiva en relación a la implementación de la realidad virtual como servicio complementario en el sector turístico, la necesidad de conocer las Tecnologías de Información y Comunicación - TIC, la sostenibilidad de los destinos turísticos y el respeto por el ambiente.

Palabras clave: Realidad virtual, sostenibilidad, destino turístico. 


\section{INTRODUCTION}

Tourism represent a continuous economic growth, with a low rate of pollution and with a projection towards sustainability (Brida, London, \& Rojas, 2014); in the peruvian case, during the last decade there were developed different kinds of activities related with tourism in the coastline region, the peruvian highlands and the peruvian jungle, for that reason tourism activities were gaining notoriety, the same that today is evolving in a dubiousness environment because of the consequences of the safety measures took by the government over the fight against the pandemic disease -COVID 19- also known as "Coronavirus".

The Peruvian Goverment had decreed, among all the measures, the compulsory social isolation, settling the required restrictions, like, no social meetings or any kind of crowds, keeping one meter of dictance in all the people, just going out of home for an emergency, etc., but at the same time the government has detemined that all the business and enterprises related to gastronomy, tourism and hostelry, under certain conditions, will return gradually to operate in the economic business sector, meanwhile this occurs there is one question that needs to be solve: Are there other alternatives to conserve the notoriety of the tourist destinations?

In these order of the ideas, it is relevant to indicate that there in no certainty about the end of the mentioned pandemic, fot that reason this research team decided to gather information about the perception of the univerity students which careers are related to the tourism business sector; considering that an unsuitable alternative of solution could affect not only entrepreneurs and enterprises, it could also became a reduction in the gained notoriety of the national tourist destinations. In front of that situation: Could it be posible that the virtual reality will be implemeneted for the tourist destinations?

According González \& Kotschack (2019), they consider that tourism is related to virtual practices, this practices are supported by an internet network, for that a set of touristic experiences without visiting the physical site are originated; for that the objective is to produce "in individuals sensations equal to or similar to reality", this concept is called post-tourism or virtual tourism (Olvera, Gea, \& González, 2019).

According For Altamirano, Marín-Gutiérrez \& Ordóñez (2018), the tourism sector should be distinguished to be "an strategic, dinamic, creative and interactive way of co- munication", in sucha way that the entry of thecnology will increase the compettitviness levels (Feierherd, González, Viera, Romano, Delia, Huertas, \& Depetris, 2019), especially that tourism is one of the biggest industry in the world Gutiérrez, Sánchez, \& Galiano, 2018), for that reason, soon or later this sector will be influenced by the Information and Communication Technologies - ICT.

The ICT revolutionized the services of tourist business (Bolzán, 2020), "transforming the hostelry industry, the restaurants and travel services" (Quiñonez-Bedón, Tapia-Pazmiño, \& Andrade-Naranjo, 2019); through the different electronic devises, the tourit has the ability to self-manage his owm decisions (Tafur, Vélez, Alejo, Zumba, \& Jacome, 2018), which is possible because of internet searching (Vega, \& Carrera, 2018).

The internet modify the concept of physical world, turning it into a nearby term for the citizens' activities (López, 2018), those who experiment this apparent contact produced by the virtual reality through catalogues and videos (Alonso, 2019), later, this cirtual reality will be knew as "extended reality", which is the result of the combination of physical reality and virtual reality (Rodríguez, \& Rosales, 2017) this combination was produced by the acquisition of knowledge (Cimatti, 2017), which will be assigned for the visualization of applications and contents (Chiliquinga, 2017).

The applications and contents issued by internet promoted the growth of tourism around the world, this fact modified the traditional concept of moving from one place to other (López, \& López, 2018), also from the personal computer and mobile devices this purpose will be achieved (Artigas, 2018), for that reason the collective knowledge was originated (Araújo, Cardoso, \& De Araújo, 2019), in front of the conservation ans sustainability of the enviorement.

On the other hand, Gómez, \& Martín (2018), said that "sustainable tourism encourage tourists and business to take care about the impact of tourism over the enviroment and prove the value of preservation of natural resources ", which needs a destination management (Torres, 2018), with public and private invesment (Sandoval, Ordoñez, \& Noblecilla, 2018), that asssure the continuity of tourist activities (Haz, Cruz, \& Sánchez, 2016) and attach the user with a correct use of technology (Algar, 2018), creating virtual products (Hernán, 2018), materialized in business 
strategies (Lalangui, Espinoza, \& Pérez, 2017), which serach to protect potential tourists.

\section{METHODOLOGY}

This investigación was dessigned under the positive paradigm, quantitative approach, analytical method, non-experimental design, descriptive level and transectional type. The main tool of this investigation was questionary of 14 items configured on the Likert scale with five alternatives: always, almost always, sometimes, almost never and never; the level of reliability of this tool was 0,935 . The population was made up of 237 students that had carried out professional practices in business related with the tourism sector. This amount of population was obtained from the academic records that this research team collect during their work as professors in the Faculties of Administration and Tourism in the Universities of Piura-Peru. The sample is represented by 147 students ( 94 men and 53 women) that voluntarily accept to participate in this investigation.

\section{RESULTS}

Now, these are the results obtained from the application of the questionnaire, they are represented in the next graph:

Graphic 1. Current perception

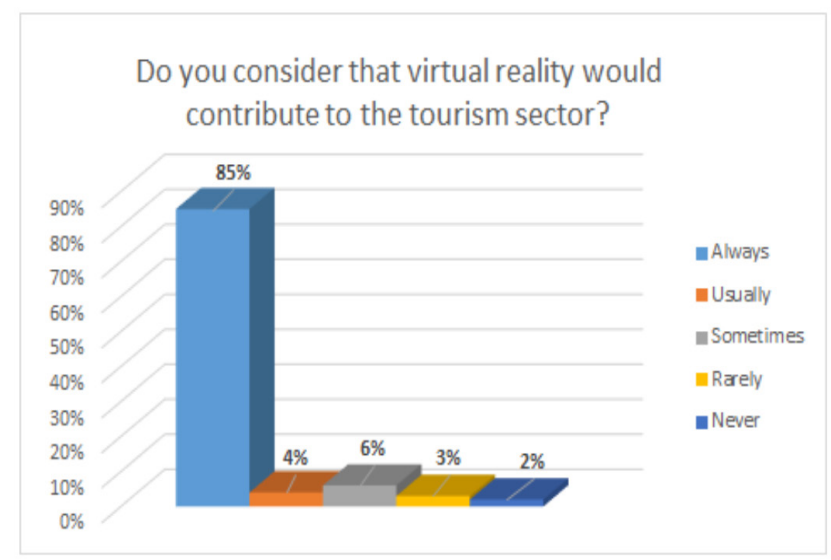

The students that had participate were informed about the importance of the proyect, which search to obtain the perspective about this topic, inside the university classroom; for that reason, the $89 \%$ of the student consider that virtual reality -always and almost always- will contribute to the tourism sector, so is important to take in account that virtual reality complement the offer of tourist services. The remaining $11 \%$ of the students have an opposite opinion about this topic.

This reseach team consider that this first mentoned percent will represent an opportunity to analize the feasibility of implement the virtual reality during extraordinary times, like the actual pandemic that the world suffers.

In that sense, It will be necessary to prepare in a shortterm period, all the university students with the technologic tools that allow them to interact and browse the internet network without major setbacks.

Graphic 2. Future perception

Is the peruvian business sector ready to resurge after a pandemic?

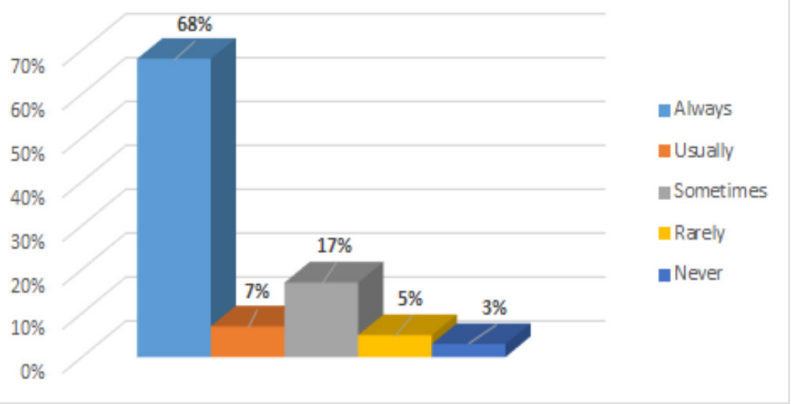

The $75 \%$ of the students consideres that the peruvian businesss sector had the possibility of resurge after the end of the pandemic, meanwhile the remaining $25 \%$ said a opposite opinion. This result was obteined from the combination of the three lastest alternatives of the Likert scale.

At this point, the research team added that the peruvian business sector related to tourism had started from zero, especially in gastronomy, so it should be innovated in a way to improve the attention service, althought it is neccesary to attend the biosecutity standars that the peruvian government had decreed for the benefit of consumers and users. 
Graphic 3. Virtual tourism perception.

\section{Does virtual tourism complement traditional tourism?}

$90 \%$

$80 \%$

$70 \%$

$60 \%$

$50 \%$

$40 \%$

$30 \%$

$20 \%$

$10 \%$

$0 \%$
-Always

-Usually

-Sometimes

Rarely

-Never

The $91 \%$ of the students considered that virtual tourism is a complement for traditonal tourism; while the remaining $19 \%$ indicated the opposite.

In this regard, it must be taken into account that virtual reality is configured by the technology to expand the the effectiveness that is carried out in certain activities, this in reason of continuing to provide an excellent service.

In the peruvian business sector related with tourism, there is no record related to the consolidation of virtual reality, being it an opportunity to implement it in a short period of time.

Graphic 4. Pandemic perception

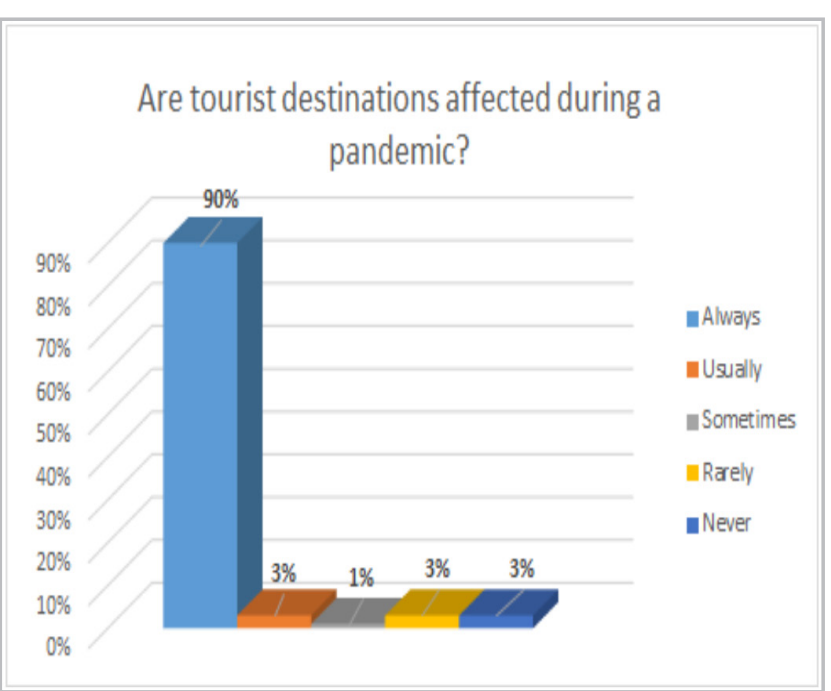

The $93 \%$ of the students considered that touristic destinations are affected by the pandemic, while the remaining $7 \%$ indicated the opposite.

In this regard, it must be taken into account that the tourist destinations encourages the start of work activities and commercial activities, in such a way that when the public does not go to tourist destinations, the effect is immediate, especially if there is a risk that a certain tourist destination is classified as high risk or that it affects the health and integrity of tourists.

For this, it requires strategies that allow not only the diffusion of the tourist destination but the loyalty with what already exists, which is why the presence and need of virtual reality applied to the tourist sector would be justified

Graphic 5. Environment perception

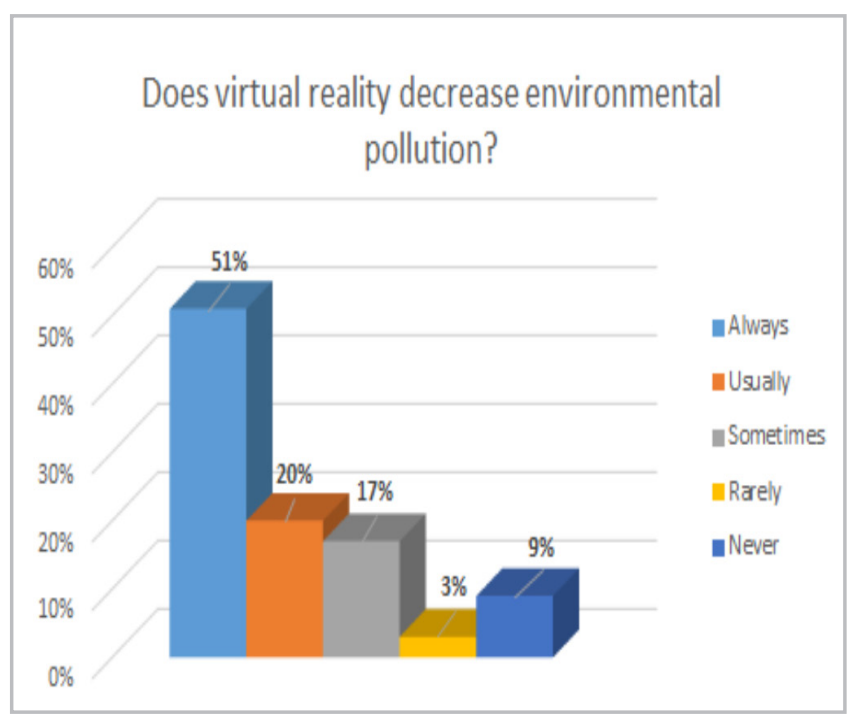

The $71 \%$ of the students said that the virtual reality reduce the environmental pollution, while the remaining $29 \%$ indicated the opposite.

In this regard, it is noted that there is a tendency to conceive the use of virtual reality for different purposes, for example in the protection of the environment, although in order to do so, environmental education must be emphasized at all levels.

The environmental pollution ia consequence of Ignorance and lack of projection in a personal capacity, since the actions of the present could cause irreparable consequences in future generations, therefore, it is necessary 
to adopt measures related to the linking of environmental awareness.

\section{Graphic 6. Costs perception}

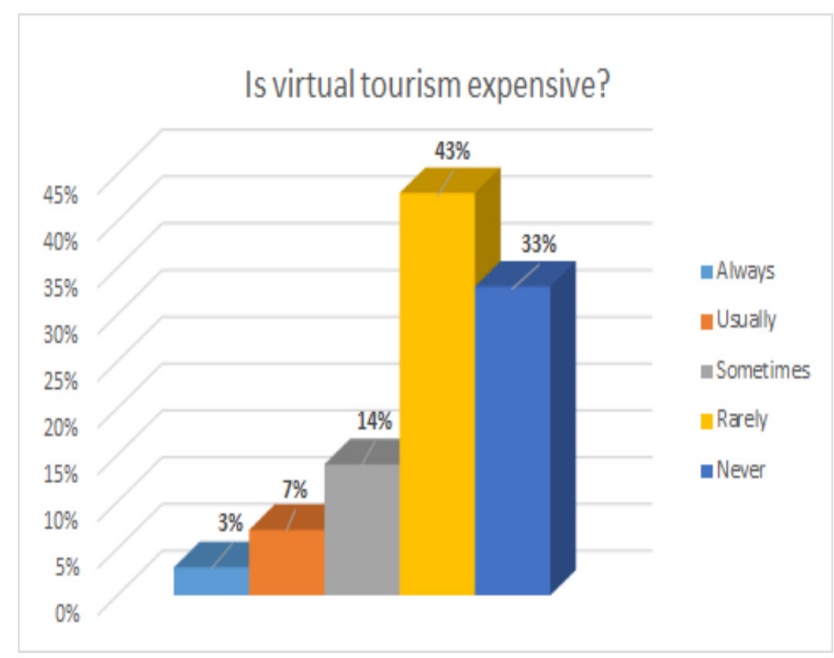

The $76 \%$ of the students said that virtual tourism is not expensive, while the remaining $24 \%$ indicated the opposite. Given this, it should be taken into account that the implementation of Information and Communication Technologies in the tourism sector will represent an investment; however, the analysis is different when there is familiarity with technological tools.

The virtual reality had been dessigned to complete the traditional business services, until now There are no known cases that led to a total displacement of the physical by virtuality.

Graphic 7. Tourist culture perception

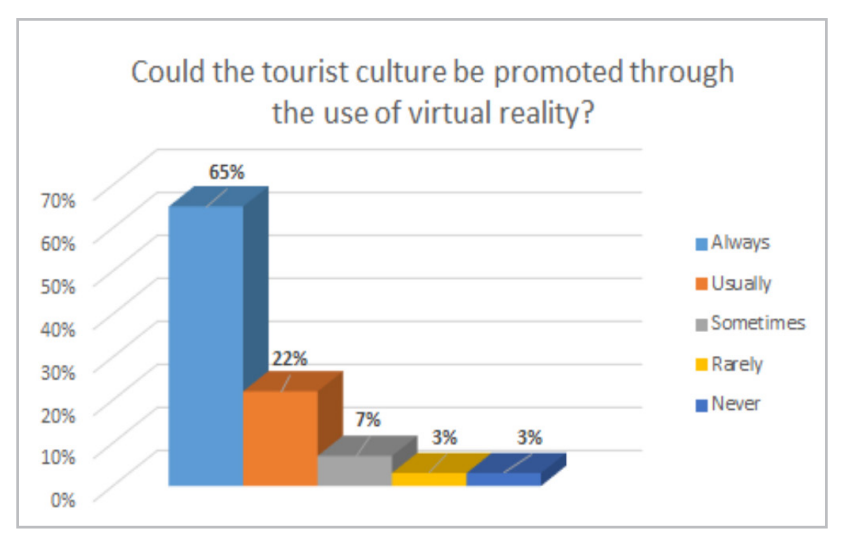

The $77 \%$ of the students said that touristic culture could be promoted through the use of virtual reality, while the remaining $13 \%$ indicated the opposite.

The virtual reality is feasible to be used for different purposes, for example, in university education, aimed at deepening concepts such as identity, solidarity, social responsibility, among others.

The research team appreciates that virtual reality in the near future will be part of human activities, therefore, it is required to know the advantages and disadvantages of its implementation.

Graphic 8. Traditional tourism perception

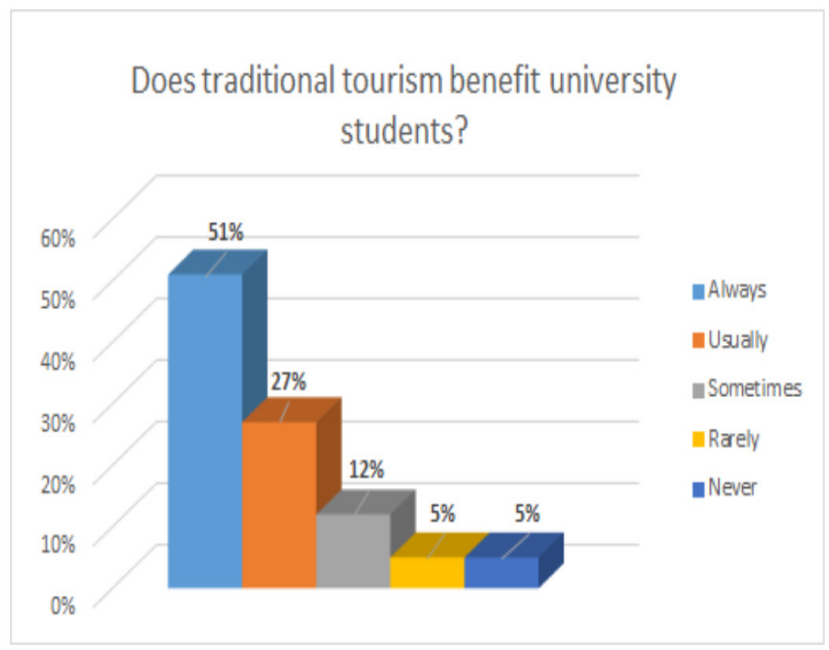

The $78 \%$ of the students said that traditional tourism benefit university students, while the remaining $22 \%$ indicated the opposite.

In this regard, it should be taken into account that the tourism sector provides the opportunity to create jobs related to translations and interpretations, receptionist, tour guides, administrators of travel agencies, customer service, among others.

However, it is evident that the current pandemic will affect the tourism sector, therefore, it is appreciated that university students could be included and be part of the unemployed population in the Peruvian territory. 
Graphic 9. Decision perception

\section{Do you consider that virtual reality allows tourists} to take the decision to prefer a certain tourist

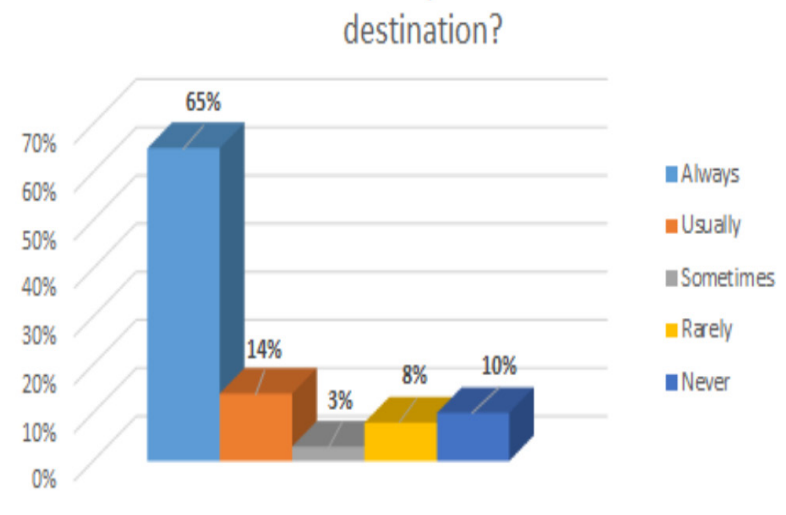

The $79 \%$ of the students considered that virtual reality allows the tourist to take the decision to prefer a certain tourist destination, while the remaining $21 \%$ indicated the opposite.

Virtual reality, as a complementary service to the tourism sector, would allow us to know in advance which tourist destinations would be essential to recognize on the next trip, thus maintaining the link between man and nature, encouraging respect and care for the environment.

Similarly, virtual reality applied correctly could contribute to the loyalty of tourists, a circumstance that would be liable for a future research.
Graphic 10. Touristic services perception

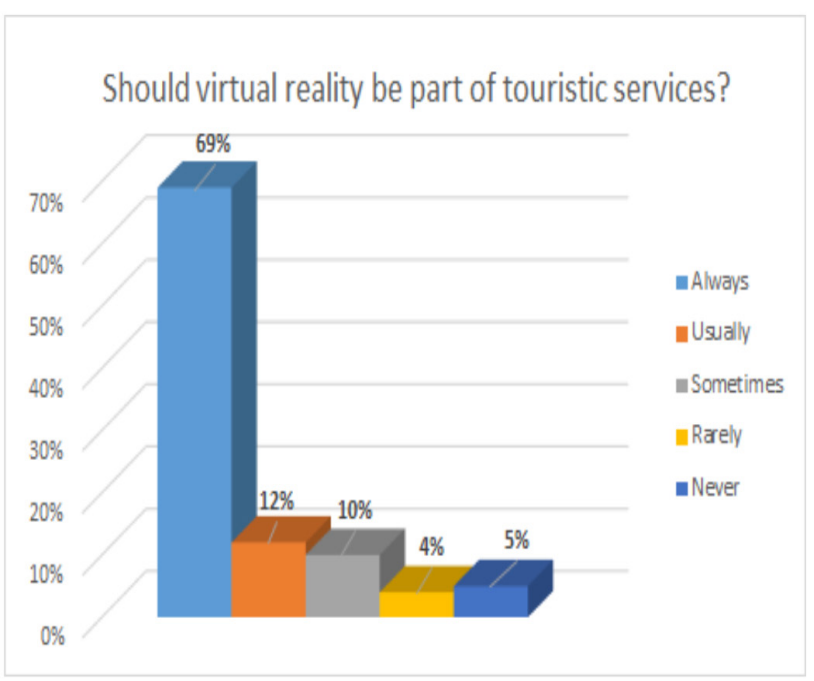

The $81 \%$ of the students considered that virtual reality should be part of touristic services,while the remaining $19 \%$ indicated the opposite.

With the consolidation of Information and Communication Technologies - ICTs, virtual reality became a necessary service in the Peruvian business sector, since it focuses its attention on the dissemination of a specific tourist destination, contributing to future tourist loyalty .

In this sense, it is necessary to reduce the digital divide in order to transmit confidence in users of the tourism sector.

Graphic 11. ICT perception

Does Information and Communication Technologies - ICT contribute to tourism?

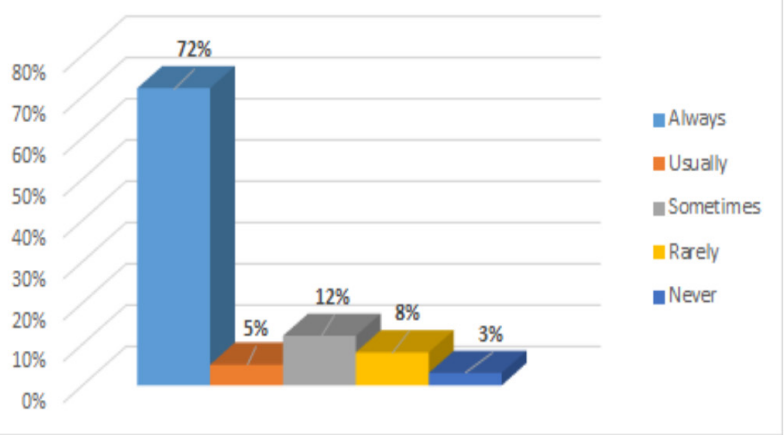


The $77 \%$ of the students considered that the Information and Communication Technologies - ICT contribute to tourism, while the remaining $23 \%$ stated the opposite.

The research team appreciates the tourism sector can not be oblivious to the use of technology, the Internet, social networks or the like that allow the demand for tourism to be viable, which is why employers must hire the appropriate personnel to carry out this function through the incorporation of strategies aimed at tourist loyalty.

Virtual reality exists to improve the service of attention in the different tourist services offered.

Graphic 12. Touristic activities perception

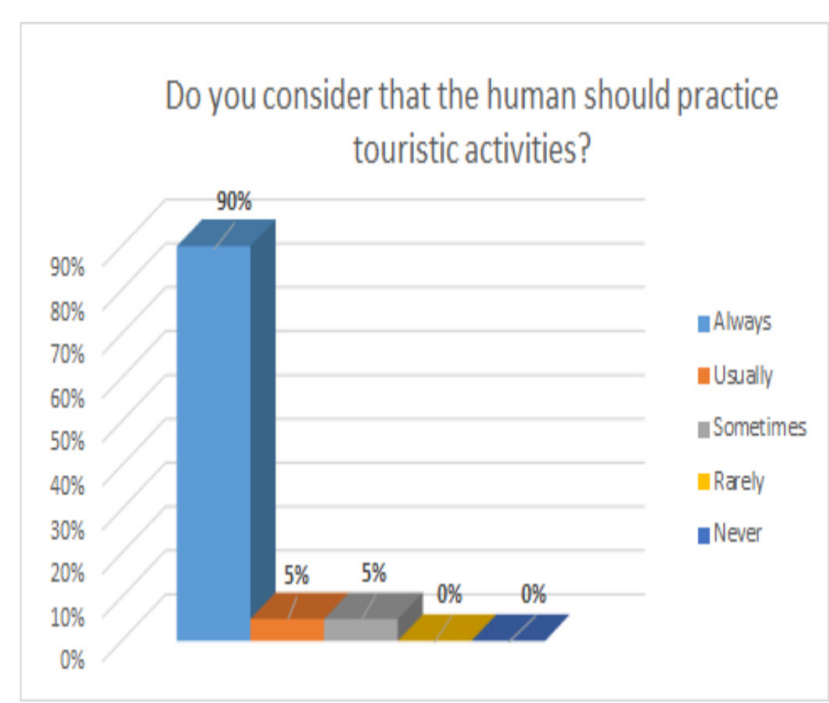

The $95 \%$ of the students considered that the human should practice touristic activities, while th remaining $5 \%$ said the opposite.

The tourist activities are conceived as the essence of the business sector in comment, they are focused on specialization according to the tastes and preferences of the tourist, who experiences various sensations, under the protection of a quality care service.

The perception of the students is remarkable to the extent that it demonstrates the need to practice tourism and in parallel the protection and care of the environment that surrounds them.
Graphic 13. Sustainability perception

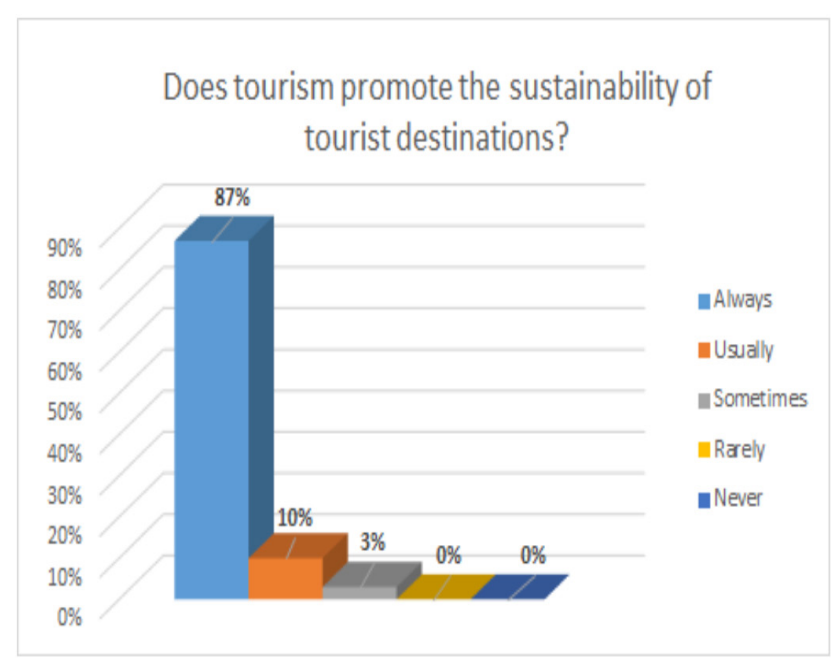

The $97 \%$ of the students considered that tourism promotes the sustainability of tourist destinations, while $3 \%$ stated otherwise.

Sustainability involves conservation, through coherent practices human behavior towards environmental care is reinforced.

In this sense, tourist destinations must be sustainable and this requires the participation of strategic actors, such as authorities, businessmen, students and the general population.

Graphic 14. Implementation perception

\section{Do you consider that virtual reality could be an alternative to be implemented in the tourism sector?}

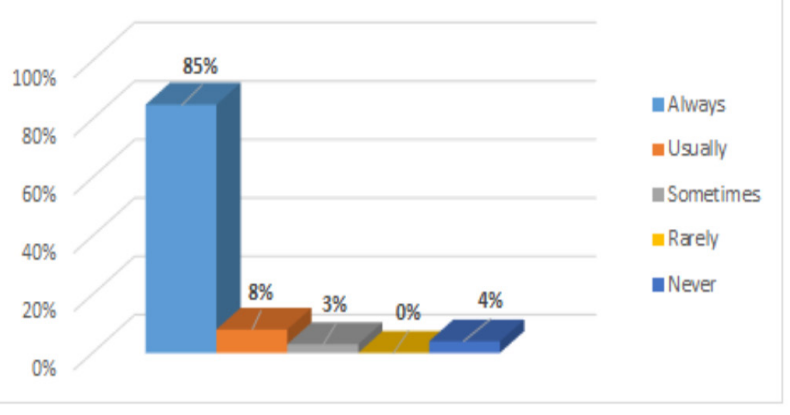


The $93 \%$ of the students considered that virtual reality could be an alternative to the implementation in the tourism sector, while $7 \%$ manifested in the other side.

The tourism sector could prepare the implementation of virtual reality in favor of the tourist, who experiences a quality service, presented in addition to the problems, obtaining a distinctive sign compared to other economic groups.

The research team appreciates the predisposition of the participants to contribute to the transformation of the traditional concept of tourism for the benefit of the business sector.

\section{CONCLUSIONS}

Virtual reality is an alternative for the sustainability of tourist destinations, for that reason is necessary the participation of authorities, businessmen, students and the general public is required to contribute with strategies aimed at the continuity of the tourist or consumer service.

The main limitations configured by the research team are related to the perception of the environment and tourist culture, since this requires the predisposition of the peruvian state to strengthen environmental education, a situation that must be addressed immediately.

The peruvian student's perception of virtual reality as an alternative for the sustainability of tourist destinations revealed that the possible beneficiaries of the implementation are represented by the business sector and the population that is directly or indirectly linked to tourism services.

\section{REFERENCES}

Algar, A. (2018). Realidad virtual aplicado al turismo. https://idus.us.es/bitstream/handle/11441/88335/Realidad_virtual_aplicada_al_ sector_turistico.pdf?sequence $=1$ \&isAllowed $=\bar{y}$

Alonso, M. (2019). Robots, inteligencia artificial y reai- dad virtual: una aproximación en el sector del turismo. https://revistas.um.es/turismo/article/ view/404711/274211

Altamirano, V., Marín-Gutiérrez, I. \& Ordónez, K. (2018). Comunicación turística 2.0 en Ecuador. Análisis de las empresas públicas y privadas. https://dialnet.unirioja.es/servlet/articulo?codigo $=6363531$

Araújo, N., Cardoso, L. \& De Araújo, A. (2019). La Comunicación 2.0 en el Sector Turístico Español: Análisis de las webs oficiales de promoción turística. http://u3isjournal.isvouga.pt/index.php/ ijmcnm/article/view/366/197

Artigas, I. (2018). La influencia de internet en la intermediación turística. https://riull.ull.es/xmlui/ bitstream/handle/915/12335/La\%20influencia\%20de\%20internet\%20en\%20la\%20intermediacion\%20turistica.pdf?sequence=1 \&isAllowed=y

Bolzán, R. E. (2020). Co-creación de calidad de servicios turísticos en comunidades virtuales. Un estudio a partir de interacciones vía web entre huéspedes y hoteles en Natal - Brasil. https://dialnet. unirioja.es/servlet/articulo?codigo $=7192844$

Brida, J. G., London, S. \& Rojas, M. (2014). El turismo como fuente de crecimiento económico: impacto de las preferencias intertemporales de los agentes. https://www.elsevier.es/es-revista-investigacion-economica-122-pdf-S0185166715300035

Chiliquinga, J. M. (2017). Realidad aumentada para la promoción turística del Cantón Pelileo. http://45.238.216.28/bitstream/123456789/7519/1/PIUASIS001-2018.pdf

Cimatti, M. L. (2017). La realidad virtual en el proceso de interpretación patrimonial. http://sedici.unlp. edu.ar/bitstream/handle/10915/74889/Documento_completo..pdf-PDFA1b.pdf?sequence $=1 \&$ isAllowed $=y$ 
Feierherd, G., González, F., Viera, L., Romano, L., Delia, L., Huertas, F. \& Depetris, B. (2019). Realidad Virtual y Aumentada, Big Data y Dispositivos Móviles: Aplicaciones en Turismo. http://sedici. unlp.edu.ar/handle/10915/77226

González, M. \& Kotschack, L. (2019). Lo físico y lo virtual en las prácticas turísticas urbanas. El caso de Buenos Aires - Argentina. https://dialnet.unirioja. es/servlet/articulo?codigo $=6871848$

Gutiérrez, G. A., Sánchez, M. A. \& Galiano, A. (2018). Redes sociales como medio de promoción turística en los países iberoamericanos. http://scielo. senescyt.gob.ec/pdf/retos/v8n15/1390-6291Retos-8-15-000135.pdf

Haz, L., Cruz, P. \& Sánchez, J. (2016). El uso de la realidad virtual como herramienta tecnológica para fomentar el turismo en la Península de Santa Elena. https://www.3ciencias.com/wp-content/ uploads/2016/09/art4-1.pdf

Hernán, L. (2018). Realidad virtual en turismo. Influencias sobre la imagen inducida de un destino. http://sedici.unlp.edu.ar/bitstream/handle/10915/73748/ Documento_completo.pdf-PDFA.pdf?sequence=1\&isAllowed=y

Lalangui, J., Espinoza, C. \& Pérez, M. (2017). Turismo sostenible. Un aporte a la responsabilidad social empresarial: sus inicios, características y desarroIlo. http://scielo.sld.cu/pdf/rus/v9n1/rus21117. pdf

López, A. L. \& López, S. A. (2018). Impacto de las TIC en el turismo: caso Colombiano. https://revistas. um.es/turismo/article/view/327081/228951

López, V. M. (2018). La realidad virtual com recurso educativo en las ciencias experimentales. https://uvadoc.uva.es/bitstream/handle/10324/30760/ TFG-B.1161.pdf?sequence=1\&isAllowed=y

Olvera, Y., Gea, M. \& González, M. (2019). Realidad virtual para dar a conocer los atractivos turísticos de Tepeapulco, Hidalgo. http://dx.doi. org/10.26457/recein.v13i50.1754

Plumed, M., Gómez, D. \& Martín, C. (2018). Planificación turística, promoción y sostenibilidad ambiental: el caso de España. http://scielo.senescyt.gob.ec/pdf/retos/v8n15/1390-6291Retos-8-15-00007.pdf

Quiñonez-Bedón, M. F., Tapia-Pazmiño, J. G. \& Andrade-Naranjo, D. S. (2019). La utilidad de las TIC en el turismo comunitario. https://dialnet. unirioja.es/servlet/articulo?codigo $=7164382$

Rodríguez, H. \& Rosales, S. (2017). Realidad aumentada para mejorar la disponibilidad de la información turística en la ciudad de Pacasmayo. http://repositorio.upao.edu.pe/bitstream/ upaorep/4200/1/RE_ING.SIST_HENRY.RODR\%c3\%8dGUEZ_STEFHĀNY.ROSALES_REALIDAD. AUMENTADA DATOS.PDF

Sandoval, D., Ordoñez, O. \& Noblecilla, M. (2018). Percepción del perfil del turista para el aprovechamiento de los atractivos turísticos: Caso Cantón Pasaje, El Oro (Ecuador). https://scieIo.conicyt.cl/pdf/riat/v14n1/0718-235Xriat-14-01-00014.pdf

Tafur, G., Vélez, C., Alejo, O., Zumba, M. \& Jacome, J. (2018). Desarrollo tecnológico del sector turístico en la ciudad de Guayaquil (Ecuador). http://www.revistaespacios.com/a18v39n44/ a18v39n44p03.pdf

Torres, P. A. (2018). Índice de éxito turístico en ciudades destino. https://www.redalyc.org/jatsRepo/1807/180755394014/180755394014.pdf

Vega, V. \& Carrera, F. (2018). El turismo a través de Internet. https://www.researchgate.net/profile/ Vladimir_Vega2/publication/329322764_El_turismo_a_traves_de_Internet/links/5c014ff4ä6fdcc1b8d4ceeed/El-turismo-a-traves-de-Internet.pdf. 